\title{
A local basis for progesterone action during mammary tumorigenesis - no longer RANK and file
}

Whitney K Petrie and Russell C Hovey*

\begin{abstract}
Two recent reports provide compelling insights into the role for RANK and its ligand, RANKL, in progestindependent mammary tumorigenesis. These findings build upon a considerable body of evidence pointing to the RANK signaling pathway as being a key mediator of progestin action in the mammary glands.
\end{abstract}

\section{Background}

The osteoblast-secreted receptor of activated NF-кB (RANK) ligand (RANKL) activates RANK receptors on osteoclasts to promote their differentiation, maturation and survival, and bone resorption [1]. More recently, these same molecules have become clearly implicated in the regulation of normal mammary development and tumorigenesis [2]. Whereas RANK is constitutively present within the mammary glands of mice, the local expression of RANKL is tightly coordinated with pregnancy-induced expansion of the mammary epithelium during lobulo-alveologenesis [3-5]. Several of the same hormones that promote this development, including progesterone, prolactin and parathyroid hormone related protein, also induce RANKL expression in the mammary glands, specifically in the mammary epithelium [3,4]. Hence, RANKL clearly fits the bill of a hormone-induced local growth factor that mediates lobulo-alveolar expansion in the mammary gland. Indeed, both female RANK and RANKL knockout mice do not lactate due to failed lobulo-alveolar development during pregnancy [3]. This RANK- and RANKLmediated development reflects both cell proliferation and survival $[3,6,7]$, which are both processes that are crucial during mammary tumorigenesis. Correspondingly, RANK is expressed by a number of breast cancer cell lines, primary breast tumors and local breast lymph node

*Correspondence: rchovey@ucdavis.edu

Department of Animal Science, University of California Davis, 2145 Meyer Hall, One Shields Avenue, Davis, CA 95616, USA metastases [2], lending strong support to a role for RANK/RANKL in breast cancer progression and metastasis.

\section{Articles}

Two recent reports [8,9] now shed important light on a role for RANK and RANKL during hormone-initiated tumorigenesis. Both studies combined progestin exposure (using the stable medroxyprogesterone acetate (MPA)) and the chemical mutagen dimethybenz[a] anthracene (DMBA) with either loss- [9] or gain-offunction [8] for RANK signaling. Consistent with a crucial role for RANK signaling, the onset, incidence and invasiveness of tumors induced by MPA/DMBA was reduced in RANK $^{\mathrm{mam}}$ mice lacking the receptor in mammary epithelial cells [9]. Conversely, mice overexpressing RANK under control of the mouse mammary tumor virus (MMTV) promoter had an increased incidence of pre-neoplastic lesions and tumors [8]. Likewise, administering RANK-Fc to antagonize RANKL decreased the total number of mammary tumors, preneoplastic lesions and the proliferation of both normal mammary epithelial cells and those in pre-neoplastic lesions [8]. The effects of MPA-induced RANKL-RANK signaling in these studies were manifest as increased cell proliferation and protection from apoptosis following DMBA-induced DNA damage [9]. RANKL also stimulated anchorage-independent growth of SKBr3 cells in vitro [9]. Moreover, tumor-initiating cells from RANK $^{\text {mam }}$ mice were unable to self renew [9] while, in the same way, epithelial cells from MMTV-RANK mice underwent inappropriate proliferation into the luminal cavity of three-dimensional acini [8]. From these results both groups concluded that RANK-RANKL induces changes consistent with transformation, a proposal that will benefit from more extensive validation.

\section{Viewpoint}

Activation of the progesterone receptor (PR) that is present in a subset of epithelial cells within the mammary glands of mice [10] stimulates those same cells to produce and secrete RANKL [11]. Recently, Brisken and colleagues [12] demonstrated that progesterone initiates two waves 
of epithelial proliferation in the mammary glands. A first, cyclin D1-dependent wave occurred in PR-positive cells and was RANKL-independent. The second round of cyclin D1-independent proliferation that occurred beyond 48 hours in PR-negative cells was then RANKLdependent [12]. This chronology of progesteroneinduced proliferation and RANKL secretion supports the model that PR-positive cells stimulate proliferation in adjacent PR-negative cells by a paracrine mechanism [10], within which there is likely a key role for RANKL. These data also suggest that progesterone induces cyclin D1 independent of RANKL. By contrast, these most recent reports $[8,9]$ and others [10] find that the progesterone-dependent induction of cyclin D1 is also RANK/RANKL-dependent. Indeed, RANKL also modulates expression of other proliferative cues, including cyclin E, Id2, and Id4 $[6,7,13]$, suggesting that multiple targets lie downstream of progesterone-induced RANK activation. The hierarchy of proliferative pathways within mammary epithelial cells that lie downstream of RANKL/ RANK may well prove to be context-specific in terms of other regulatory events, including the effects of other hormones or growth factors, the extracellular matrix, or pregnancy-associated differentiation. Indeed, both prolactin and parathyroid hormone-related peptide are capable of inducing RANKL in the mammary glands [3] while others reported that estrogen was required to facilitate progesterone-induced RANKL expression [4].

As pointed out by both groups, the present findings may firmly implicate RANK as a key player during progesterone-dependent breast cancer, given that women receiving combined estrogen plus progesterone replacement therapy, but not estrogen alone, have an increased risk of developing breast cancer [14]. However, any effect of progestins such as MPA on breast cancer risk, and therefore RANK signaling, presents an opportunity for detailed resolution given that MPA at comparable doses also serves as the primary progestin in hormonal contraception that has no consistent effect on breast cancer risk [15]. Therefore, the role of progesterone and RANK/ RANKL during breast cancer onset may well prove to be context-specific. Along these lines, different strains of mice respond differently to progesterone in terms of both mammary development and RANKL expression [13]. Likewise, in both of the present studies the ability of RANK to mediate MPA-dependent tumorigenesis was enhanced by DMBA that induces a unique mammary cancer pathotype distinct from that typical for human breast cancer [16].

In conclusion, these important recent findings lend support to a growing body of data pointing to a key role for RANK and its ligand during progestin-dependent epithelial proliferation and cancer in the mammary glands. These findings may prove to be even more important for delineating the role of RANK and RANKL in managing hormone-dependent and/or -independent breast cancer.

\section{Abbreviations}

DMBA, dimethybenz[a]anthracene; MMTV, mouse mammary tumor virus; MPA, medroxyprogesterone acetate; PR, progesterone receptor; RANK, receptor of activated NF-KB; RANKL, RANK ligand.

\section{Competing interests}

The authors declare that they have no competing interests.

Published: 28 January 2011

\section{References}

1. Hofbauer LC, Rachner T, Singh SK: Fatal attraction: why breast cancer cells home to bone. Breast Cancer Res 2008, 10:101.

2. Jones DH, Nakashima T, Sanchez OH, Kozieradzki I, Komarova SV, Sarosi I, Morony S, Rubin E, Sarao R, Hojilla CV, Komnenovic V, Kong YY, Schreiber M, Dixon SJ, Sims SM, Khokha R, Wada T, Penninger JM: Regulation of cancer cell migration and bone metastasis by RANKL. Nature 2006, 440:692-696

3. Fata JE, Kong YY, Li J, Sasaki T, Irie-Sasaki J, Moorehead RA, Elliott R, Scully S, Voura EB, Lacey DL, Boyle WJ, Khokha R, Penninger JM: The osteoclast differentiation factor osteoprotegerin-ligand is essential for mammary gland development. Cell 2000, 103:41-50.

4. Srivastava S, Matsuda M, Hou Z, Bailey JP, Kitazawa R, Herbst MP, Horseman ND: Receptor activator of NF-kappaB ligand induction via Jak2 and Stat5a in mammary epithelial cells. J Bio/ Chem 2003, 278:46171-46178.

5. Gonzalez-Suarez E, Branstetter D, Armstrong A, Dinh H, Blumberg H, Dougall WC: RANK overexpression in transgenic mice with mouse mammary tumor virus promoter-controlled RANK increases proliferation and impairs alveolar differentiation in the mammary epithelia and disrupts lumen formation in cultured epithelial acini. Mol Cell Bio/ 2007, 27:1442-1454.

6. Kim NS, Kim HJ, Koo BK, Kwon MC, Kim YW, Cho Y, Yokota Y, Penninger JM, Kong YY: Receptor activator of NF-kappaB ligand regulates the proliferation of mammary epithelial cells via Id2. Mol Cell Bio/ 2006, 26:1002-1013

7. Fernandez-Valdivia R, Mukherjee A, Creighton CJ, Buser AC, DeMayo FJ, Edwards DP, Lydon JP: Transcriptional response of the murine mammary gland to acute progesterone exposure. Endocrinology 2008, 149:6236-6250

8. Gonzalez-Suarez E, Jacob AP, Jones J, Miller R, Roudier-Meyer MP, Erwert R, Pinkas J, Branstetter D, Dougall WC: RANK ligand mediates progestininduced mammary epithelial proliferation and carcinogenesis. Nature 2010, 468:103-107.

9. Schramek D, Leibbrandt A, Sigl V, Kenner L, Pospisilik JA, Lee HJ, Hanada R, Joshi PA, Aliprantis A, Glimcher L, Pasparakis M, Khokha R, Ormandy CJ, Widschwendter M, Schett G, Penninger JM: Osteoclast differentiation factor RANKL controls development of progestin-driven mammary cancer. Nature 2010, 468:98-102.

10. Mukherjee A, Soyal SM, Li J, Ying Y, He B, DeMayo FJ, Lydon JP: Targeting RANKL to a specific subset of murine mammary epithelial cells induces ordered branching morphogenesis and alveologenesis in the absence of progesterone receptor expression. FASEB J 2010, 24:4408-4419.

11. Mulac-Jericevic B, Lydon JP, DeMayo FJ, Conneely OM: Defective mammary gland morphogenesis in mice lacking the progesterone receptor $B$ isoform. Proc Natl Acad Sci U S A 2003, 100:9744-9749.

12. Beleut M, Rajaram RD, Caikovski M, Ayyanan A, Germano D, Choi Y, Schneider P, Brisken C: Two distinct mechanisms underlie progesterone-induced proliferation in the mammary gland. Proc Natl Acad Sci U S A 2010, 107:2989-2994.

13. Aupperlee MD, Drolet AA, Durairaj S, Wang W, Schwartz RC, Haslam SZ: Strainspecific differences in the mechanisms of progesterone regulation of murine mammary gland development. Endocrinology 2009, 150:1485-1494.

14. Chlebowski RT, Anderson GL, Gass M, Lane DS, Aragaki AK, Kuller LH, Manson JE, Stefanick ML, Ockene J, Sarto GE, Johnson KC, Wactawski-Wende J, Ravdin PM, Schenken R, Hendrix SL, Rajkovic A, Rohan TE, Yasmeen S, Prentice RL; WHI Investigators: Estrogen plus progestin and breast cancer incidence and mortality in postmenopausal women. JAMA, 304:1684-1692.

15. Breast cancer and hormonal contraceptives: further results. Collaborative Group on Hormonal Factors in Breast Cancer. Contraception 1996, 
54(3 Suppl):1S-106S

16. Currier N, Solomon SE, Demicco EG, Chang DL, Farago M, Ying H, Dominguez I, Sonenshein GE, Cardiff RD, Xiao ZX, Sherr DH, Seldin DC: Oncogenic signaling pathways activated in DMBA-induced mouse mammary tumors. Toxicol Pathol 2005, 33:726-737.

\section{doi:10.1186/bcr2802}

Cite this article as: Petrie WK, Hovey RC: A local basis for progesterone action during mammary tumorigenesis - no longer RANK and file. Breast Cancer Research 2011, 13:301. 